\author{
А. М. Ранчин \\ Московский государственный университет \\ (Россия, Москва) \\ Шанхайский педагогический университет \\ (Китай, Шанхай) \\ aranchin@mail.ru
}

\title{
К ВОПРОСУ О НЕОЛОГИЗМАХ В ПОЭЗИИ ИОСИФА БРОДСКОГО
}

В статье рассматриваются неологизмы в поэтических текстах Иосифа Бродского. Основной предмет исследования - окказионализм неврастение из стихотворения «Квинтет» (1977). У этого неологизма можно найти четыре значения, возникающих благодаря разному пониманию грамматических признаков, морфемных швов и предполагаемых словоразделов. Семантически многомерный неологизм строится на основе развернутой метафоры со сложным чередованием означающих и означаемых элементов. Также в статья анализируются более простые в семантическом отношении неологизмы из этого и ряда других стихотворений Бродского. Неологизмы в поэзии Иосифа Бродского, во многом ориентированной на классическую литературную традицию, немногочисленны. Неологизмы Бродского часто строятся на основе приемов каламбурного рода (сдвиг границ слова или морфем, ложная этимологизация и игра на создаваемой омонимии окказионализма и словарного слова), но лишены комизма. Неологизмы у Бродского, с одной стороны, знаки катастрофы или цивилизационного кризиса, они - симптомы некоей “болезни языка". Иногда это знаки катастрофы, безумия, которое овладевает лирическим героем. Это сигналы обрыва коммуникации. Неологизмы могут обозначать ситуацию отчуждения. С другой же стороны, это один из наиболее ярких примеров креативной роли языка, о которой неизменно писал поэт.

Ключевые слова: поэзия Иосифа Бродского, неологизмы, окказионализмы, метафора, словоразделы, морфемные швы.

Неологизмы в поэзии Иосифа Бродского, во многом ориентированной на классическую литературную традицию, немногочисленны. Наиболее интересный случай — стихотворение «Квинтет» (1977). Последняя его строфа пятой, заключительной части содержит неологизм неврастение: 
Это - записки натуралиста. За-

писки натуралиста. Капающая слеза

падает в вакууме без всякого ускоренья.

Вечнозеленое неврастение, слыша жжу

це-це будущего, я дрожу,

вцепившись ногтями в свои коренья.

Этот неологизм у Бродского - окказионализм, который нельзя рассматривать в качестве потенциального слова, если подразумевать под последним лексему, способную стать словарной. Этот окказионализм создается в результате интерференции нескольких лексем и потому обладает семантической многомерностью. Такая многомерность возникает, во-первых, благодаря возможности по-разному трактовать грамматические признаки неологизма неврастение, а во-вторых, благодаря возможности различным образом устанавливать словоразделы. Я - неврастение - это пример метафоры, являющейся трансформацией т. н. метафорыкопулы ${ }^{1}$. Неологизм — элемент этой метафоры — может быть понят различным образом.

Первая интерпретация: это метафора 'я - нервное растение' (растение-неврастеник). При такой трактовке неврастение является означающим для реконструируемого на глубинном уровне текста целого словосочетания * растение-неврастеник или *неврастеничное растение. Допустимо полагать, что словосочетание *неврастеничное растение подвергается компрессии, при которой однозначное установление морфемного шва становится невозможным, так как происходит интерференция лексем: нев[растеничное]растение или неврастени[чное растени]е. (В квадратные скобки взяты «вычеркнутые» фрагменты лексем.) Но также возможно представить неврастение результатом метатезы вместе с исключением части второго слова в исходном выражении *растение-неврастеник: нев[растеник]растение.

Вторая интерпретация: это «отрицательная» метафора 'я — не растение' (не в растение = вышел не в растение, вырос не в растение). В этом случае возникает семантический конфликт между неологизмом и его атрибутом - прилагательным вечнозеленое, указывающим, что определяемое слово означает именно 'растение'. Однако у Бродского, любящего прием, названный мною самоотрицанием [Ранчин 2001: 58-61, 65], такие противоречия оксюморонного свойства встречаются.

Третья интерпретация: это грамматический неологизм с семантикой 'неврастеник’ (с трансформацией грамматической категории рода - из мужского в средний). Такая трактовка может показаться избыточной, так как на первый взгляд покрывается, охватывается первой интерпретацией. Однако это не совсем так: в последнем случае актуализируется несоответствие подразумеваемого мужского рода слова неврастеник и мужского пола лирического я среднему роду неологизма неврастение. Посредством грамматики выражается такой смысл, как развоплощение,

\footnotetext{
${ }^{1}$ См. о ней [Полухина 2009: 184-204].
} 
аннигиляция этого лирического я, словно превращающегося в безликое оно. Схожий пример в литературной традиции: последовательное употребление выражения среднего («неодушевленного») рода значительное лиц̧о при обозначении крупного чиновника в повести Николая Гоголя «Шинель». У самого Бродского в стихотворении «Ниоткуда с любовью, надцатого мартобря...» из цикла «Часть речи» (1975-1976) встречается пример размывания признаков пола адресата (мужской/ женский); это размывание создается с помощью игры грамматическими признаками мужского и женского рода в обращениях:

Ниоткуда с любовью, надцатого мартобря, дорогой, уважаемый, милая, но неважно даже кто, ибо черт лица, говоря откровенно, не вспомнить <...

Любопытно, что в этом тексте игра грамматическими признаками рода сочетается, так же как и в «Квинтете», с неологизмом (мартобря), причем этот неологизм заимствован именно из Гоголя - из его повести «Записки сумасшедшего».

Четвертая интерпретация: $я$ - неврастение - это трансформация высказывания * я не врастаю. Неврастение в этом случае можно трактовать как окказиональное образование с постфиксом -еnij- от глагола (не) врастать. Художественная семантика этой метафоры: 'я - не укоренен в земле, в почве, я одинок, как перекати-поле'. Лирическое я вцепляется в свои коренья, ибо они (корни) не в земле.

Разные значения неологизма поддерживаются дальнейшим непредсказуемым развитием метафоры в двух планах - прямом и переносном. Выражение вцепивиись ногтями употреблено вместо словосочетания * вцепивиись корнями, подразумеваемого и ожидаемого при развертывании метафоры $я-$ растение. Замещаемый элемент метафоры, ее означаемое - человек, лирическое $я$ - оказывается прямо выражен в тексте посредством относящегося к этому я слова ногтями, которое может характеризовать человека, но никак не растение. Таким образом, как будто бы получается, что не только растение является метафорой человека, лирического я, но и само это $я$, человек словно становится означающим элементом метафоры для растения; совершается взаимная метаморфоза растения и человека. Далее происходит нарушение уже этой новой логики развертывания метафоры и возвращение к означиванию лирического $я$ посредством растительной метафоры. Выражение в свои коренья использовано вместо словосочетания * в свои колени, ожидаемого при развертывания прямой характеристики лирического я. Метафора вьется, как лента Мёбиуса, и в конце концов замыкается в самой себе: растение $\rightarrow$ лирическое $я \rightarrow$ растение. Метафора как бы вцепляется сама в себя, как человек-неврастеник ногтями в собственные колени / коренья. Сама композиция метафоры семантизируется, а в метафоре выявляется ее метауровневая, метаязыковая природа, вообще свойственная этому тропу, как показывает Поль Рикер [Ricoeur 1993: 138-143].

Таким образом, неологизм неврастение функционирует с помощью игры со сдвигом границ между подразумеваемыми (окказионально выделяемыми) 
и одновременно элиминируемыми словами или морфемами: отрицательной частицей не, префиксом не-, предлогом в и остальной частью слова (производящей основой), начинающейся, при одной из интерпретаций с префикса 8 - (врастать), а при другой интерпретации - сразу с корня раст-. Варианты разбивки на слова или морфемы: не-врастение, нев-растение, не-в-растение. Такая игра со сдвигом границ между словами и/или морфемами поддерживается внутрисловным enjambement на границе 1-й и 2-й строк фрагмента, позволяющим понять лексему «за- / писки» не только как 'дневник, воспоминания', но и как неологизм-окказионализм со значением 'запредельные, громкие писки'. Своеобразным метаописанием такой игры является высказывание Помнит ли цуелое роль частиц? в первой строфе пятой части стихотворения.

Во второй строфе четвертой части содержится неологизм жидопись: В одинокой комнате простыню / комкает белое (смуглое) просто ню - / жидопись неизвестной кисти. Неологизм строится на основе замены всего лишь одной буквы: $\partial$ вместо в. «Окказионализация» подразумеваемой лексемы *живопись сочетается в этой строке с трансформацией на уровне семантической сочетаемости: одинокая комната вместо *одинокий обитатель комнатьл или вместо *одиночная камера.

В «Квинтете» окказионализмы - свидетельство некоего кризиса и признак цивилизационной катастрофы, обратной эволюции мира к небытию. Отчасти аналогичный случай - например, уже процитированное стихотворение «Ниоткуда с любовью, надцатого мартобря...», в котором окказионализм надияатого мартобря, отсылающий к гоголевским «Запискам сумасшедшего», - знак катастрофы, безумия, которое обстает лирического героя. Обрыв коммуникации в стихотворениях цикла «Часть речи» может проявляться не только в «разрушении» лексем, но и в утрате синтаксической и семантической связности предложения, как это происходит в стихотворении «Узнаю этот ветер, налетающий на траву...»².

Неологизм-окказионализм может обозначать ситуацию отчуждения, как тихотворенье вместо подразумеваемого *стихотворенье («Тихотворенье мое, мое немое...» из того же цикла); отчуждение, «отрезание» здесь иконически выражено отсечением начальной буквы: Ломоть отрезанный, тихотворенье. Несколько иначе трансформация традиционной семантики происходит у лексемы телосложенье в стихотворении «Пчелы не улетели, всадник не ускакал. В кофейне...» (1989) слово приобретает окказиональное значение 'сложение, положение тел [убитых в сражении]' [Лосев 2011: 485]. Также к числу сложных случаев можно отнести неологизм бесстужев с двойной семантикой: 'отсутствие стужи / потепление' и ‘декабрист М.П. Бестужев-Рюмин’ в стихотворении «О если бы птицы пели и облака скучали...» (1994). При этом окказионализм бесстужев предстает заменой другого окказионализма — *бесстужие [Ранчин 2001: 49]. В этом случае появление неологизма сигнализирует о ситуации отчуждения - и от времени, и от бытия.

Неологизмы Бродского часто строятся на основе приемов каламбурного рода (сдвиг границ слова или морфем, ложная этимологизация и игра на создаваемой

${ }^{2}$ См.: [Ранчин 2002: 199-203; Двинятин 2011: 289, 297-298]. 
омонимии окказионализма и словарного слова), но лишены комизма. Неологизмы у Бродского, с одной стороны, знаки катастрофы или цивилизационного кризиса, они - симптомы некоей «болезни языка». С другой же стороны, это один из наиболее ярких примеров креативной роли языка, о которой неизменно писал поэт.

\title{
Литература
}

Двинятин Ф. Еще о межъязыковых звукосмысловых соответствиях в поэзии Бродского // Новое литературное обозрение. 2011. № 112. С. 288-299.

Лосев Л. В. Примечания // Бродский И. Стихотворения и поэмы: В 2 т. / вступит. ст., сост., подгот. текста и примеч. Л.В. Лосева. СПб.: Издательство Пушкинского Дома; Издательство «Вита Нова», 2011. Т. 2. С. 329-539.

Полухина В. Грамматика метафоры и художественный смысл // Полухина В. Больше самого себя: О Бродском. Томск: ИД СК-С, 2009. С. 177-212.

Ранчин А. На пиру Мнемозины: Интертексты Иосифа Бродского. М.: Новое литературное обозрение, 2001. 464 с.

Ранчин A. Три заметки о полисемии в поэзии Иосифа Бродского // Новое литературное обозрение. 2002. № 56. С. 199-203.

Ricoeur P. The Rule of Metaphor: Multi-Disciplinary Studies of the Creation of Meaning in Language / transl. by R. Czerny with R. McLaughlin and J. Costello. SJ. Toronto; Buffalo; London: University of Toronto Press, 1993. VIII, 384 p.

\author{
A. M. Ranchin \\ Moscow State University \\ (Russia, Moscow) \\ Shanghai Normal University \\ (China, Shanghai) \\ aranchin@mail.ru
}

\section{ON THE QUESTION OF NEOLOGISMS IN THE POETRY OF JOSEPH BRODSKY}

The paper investigates neologisms in the poetic texts of Joseph Brodsky. The main subject of the study is an occasionalism nevrastenie from the poem "Quintet" (1977). This neologism contains four meanings, arising from different understanding of grammatical features, morphemic sutures, and word divisions. Semantically multidimensional neologism is built on the basis of a detailed metaphor with a complex alternation of the signifiers and signified elements. Also, the paper analyzes neologisms from different poems by Brodsky. Brodsky's poetry is generally oriented toward the classical literary tradition, therefore the number of neologisms is rather few and insignificant. Brodsky's neologisms are often built on the basis of puns. The devices used by the author are the 
following: a shift on the boundaries of the word or morpheme, false etymologization and interplay on the created homonymy of occasionalism and real word, belonging to vocabulary. But these neologisms invented by Brodsky are devoid of the comic. The neologisms of Brodsky, on the one hand, work as signs of a catastrophe or a civilizational crisis, they are symptoms of a "disease of language". Sometimes these occasional words are signs of a catastrophe, of insanity that captures a lyrical hero. These neologisms are signals of a communicative failure. Neologisms can denote the situation of alienation. On the other hand, these occasionalisms are one of the most striking examples of the creative role of language, invariably stressed by the poet.

Key words: the poetry of Joseph Brodsky, neologisms, occasionalisms, metaphor, word boundaries, morphemic sutures.

\section{References}

Dvinyatin F. [More on interlingual sound-and-meaning correspondences in the poetry of Joseph Brodsky]. Novoe literaturnoe obozrenie, 2011, no. 112, pp. 288-299. (In Russ.)

Losev L. V. [Commentaries]. Brodskii I. Stikhotvoreniya i poemy: V dvukh tomakh (tom vtoroi), vstupit. st., sost., podgot. teksta i primech. L. V. Loseva [Brodsky J. Poems. In two volumes. Preface, preparation of text and commentaries by L.V. Losev (volume 2], St. Petersburg, Pushkin House Publ., Vita Nova Publ., 2011, pp. 329-539. (In Russ.)

Polukhina V. [Grammar of metaphor and the literary meaning]. Polukhina V. Bol'she samogo sebya: O Brodskom [Polukhina V. More than himself: About Brodsky]. Tomsk: ID SK-S Publ., 2009, pp. 177-212. (In Russ.)

Ranchin A. [Three notes on polysemy in the poetry of Joseph Brodsky]. Novoe literaturnoe obozrenie. 2002, no 56, pp. 199-203. (In Russ.)

Ranchin A. Na piru Mnemoziny: Interteksty Iosifa Brodskogo [At the feast of Mnemosyne: Intertexts of Joseph Brodsky]. Moscow, Novoe literaturnoe obozrenie, 2001. $464 \mathrm{p}$.

Ricoeur, P. The Rule of Metaphor: Multi-Disciplinary Studies of the Creation of Meaning in Language / transl. by R. Czerny with R. McLaughlin and J. Costello, SJ. Toronto; Buffalo; London, University of Toronto Press, 1993, VIII, 384 pp. 